\title{
Theoretical-pedagogical Issues of Forming Professional Competence of Future Philology Specialists on the Basis of Kazakh Language Historical Grammar and Terms
}

\author{
Zh.Belassarova ${ }^{1}$ \\ A.Sarbalina ${ }^{2}$ \\ M.Zhunissova ${ }^{3}$ \\ M.Azhgaliev ${ }^{4}$ \\ Zh.Zhunissova ${ }^{5}$ \\ A.Ortayeva ${ }^{6}$ \\ T.S.Tebegenov ${ }^{7}$ \\ PhD Doctoral candidate, Kazakh National Pedagogical University named after Abai \\ 2 PhD Doctoral candidate, Kazakh State Women's Teacher Training University \\ ${ }^{3}$ Candidate of Philology, associate professor, Kazakh National Pedagogical University named after Abai \\ ${ }^{4}$ Candidate of philology, West-Kazakhstan University of Engineering and Humanities \\ ${ }^{5}$ Candidate of Philology, L.N.Gumilyov Eurasian National University \\ ${ }^{6}$ Senior Teacher, South Kazakhstan State Pedagogical Institute \\ ${ }^{7}$ Doctor of Philology, Professor, Kazakh National Pedagogical University named after Abai
}

\section{Doi:10.5901/mjss.2015.v6n4s2p417}

\section{Abstract}

In modern economical state the issue of improvement of future specialist's professional competence comes from requirements of the era. In state program of the RK 2020 about education, improvement of professional competence is among important problems that need to be solved. Also increase the demands for teachers who can develop their actions by creative and resourceful side and can use scientific achievements and best pedagogical experiences. This kind of teacher is responsible for development and education of schoolchildren.

Keywords: historical grammar, competence, professional competence, morphology, Turkic languages, classification, ancient writing monuments;

\section{Introduction}

Requirements to our country to correspond world standards are directly related to teachers. Researchers offer the following 5 direction in formation of competence:

1 administrative, 2 pedagogical, 3 professional, 4 educational, 5 informational. The most complex among them is professional direction.

Russian scientists V.A.Adolf, N.V.Kuzmina, A.K.Markova, E.F.Zeer and etc. in their pedagogical study say that the issue of professional competence of teachers is interesting.

Foreign philosophers like D. Dewey, W.Waller. M.Meed considered professional competence as actions those human needs to adapt the environment. And said that person's profession leads to his interest in something, loyalty to his job and determination to reach his aims.

The term "competence" is often used in connection with the owner of certain social-professional status and his notion in doing his job, knowledge described through correspondence of his solutions of the problems on its level.

In "Glossary of methodological terms" it's said "Competence (from Latin competentis "coinciding") is a knowledge formed in the process of teaching certain subjects, set of skills as well as ability to perform any work."

In Russian glossary, the term "competence" is given as "person's being well aware in certain area."

The word "compete" in Latin means "to know", "to be able to do", "achieve". In wide range it defines the meaning of 
competence. To define categories of professional competence it's necessary to change them, specify and unite in general logical notion.

"Competence" in literature means the integration of knowledge and possibility, results of researches, person's capability to implement his features through general cultural and complex units, his ability to create necessary communication with others and etc. It's direction of realization of young researchers' competence in scientific researches and individual's psychological, theoretic, methodological, technological preparedness in meeting its requirements.

According to new view in modern pedagogic, its aim is not giving the basic knowledge but to teach to use that knowledge creatively in real life situations, and also to prepare them for self-development through forming subject competence, to understand environmental truth, to feel their individuality, to acquire basic learning and communication skills.

In this inconstant time, state of education is full of contrasts around the world too. Development of society has always been ahead of education, sometimes this gap is measured in decades. Each day human receives lots if information, but content of learning and methods of teaching is left behind. That's why contrasts in education between social necessity and satisfaction of those these necessities resulted in crisis in education. For this reason we need to organize development of teachers' skills on the basis of their professional competence.

\section{Main Part}

As for term competence, I.N. Schpilrain, S.G.Gellerstein, E.A.Klimov (Klimov, 2003) and other psychologists said that it's an ability to solve problems that we face on everyday life.

According to A.K.Markova professional competence is future specialist's psychological function on high level, his achievements in teaching children, professional; mastery and etc (Markova, 1996).

We think that professional competence is specialist's efficiency not only in his own sphere but in educational, pedagogical, psychological spheres, and being able to teach them as a basic knowledge and to use them in real life situation, inspire to achieve the goals. From professional it's required to methodological and theoretical knowledge based on pedagogics. Young specialist forms professional knowledge and professional skills through experience.

Future philologists' professional competence need to be taken in connection with historical grammar in Kazakh linguistics. The main object of historical grammar is structure of language in the process of formation of the Kazakh nation. Any problem of the language history, especially history of phonetics system and grammar structure relies on the notion of differences of the modern language structure's new phase and traces of ancient times. If a certain regularity is settled systematically, in another language it left as episodic intention, that's why comparison of language of old heritage and modern language facts can't fully show the road that grammar have went. And it leads to the necessity to compare the facts of kindred languages. These comparisons are not going to destroy language's significance in the society.

Nowadays formation of Kazakh language history, its development from informative and service sides connected with the distribution of nominal words and verbs. M.Tomanov, who found the main reason of distribution says "phonetic similarity created in the process of historical development". These is why similar words were not single separate words in the ancient time, but were syntactical elements that differed from each other within the context. The researcher not only names the nominal words, but also explains their origin, evolution and grammatical categories.

M.Tomanov was the first to write grammatical history of Kazakh language relying on scientific opinions and conception in Turkic language. His work is still recognized as unique and distinctive.

Markhabat Tomanov also wrote comparative grammar of Turkic languages and confirmed in Turkology. He showed the main features of phonetic and morphologic structure in Turkic languages by complex and comparative study of old data and could find main systemic peculiarities of Turkic languages, as well as common features. Given the modern Turkic nations formed from tribes that spoke in different dialects according to their social, historical features, he determined main track that started the literary language, the main linguistic regularities. He also could prove that in the last 1500 year, Turkic people frequently communicated with other countries, populated wide range of lands, assimilated languages of non-Turkic speaking countries and gave them Turkic characteristics.

Kazakh language became known as young language among group of Turkic languages. Despite the fact5 that it has grammatical structure that went through complex process of formation and has a history of formation, a well-known scientist of Turkology in Soviet time S.Malov has grouped age of languages as following:

- the oldest languages

- old languages

- new languages

- the newest languages 
He included Kazakh language in the group of the newest languages. Despite considering it as the newest language, he has researches on the grammatical history of Kazakh language. Even though M.Tomanov says that in order to deeply study writing works. This opinion is widely supported in the latest works.

At anytime, opposing the opinions of respective scientist and giving new point of view was not an easy thing. M.Tomanov was the one who proved, with detailed scientific studies and historical evidences that Kazakh language can't be the newest language in comparison with other Turkic languages, because their root is common and has the same way of development. The researcher used the fact that our words often start with hard consonants as basis and opposed the idea that Kazakh is the newest language, because hard consonants are old historical process. He admits his disagreement with Malov's idea and concludes: "...in Kazakh language ration between hard and voiced consonants is approximately equal, old sounds combinations like rt, It, nt are preserved in words. But these features are not new in Kazakh language, it can be the evidence that it started to be formed in early years" (Tomanov, 1988).

As for formation of Kazakh language grammar, professor Tomanov studied ancient Turkic monuments not only from linguistic perspective, but also as literary, historical and archeological heritage. Now this issue is addressed from complex perspective. For example, during the systematization if a research written in X-XV centuries, the scientist says; "it's a time when Kazakh's rich oral literature was born and written literature started to form". Thus, he studies oral and written literature in succession and determines their place and own features. These thoughts lead latest researches to build their own relation regarding to folklore. Also works of oral literature gain significance in determining language history. He didn't only make Kazakh and old Turkic languages word speak, but also studied linguistic evidences comparing in a real direction and altaistic level.

Tomaniv uses Kashgari's "Diwani lugat at Turik" as collection of oral language. We think that it's a fair evaluation, because we know that proverbs and sayings used as examples on Kashgari's work are the instances or oral literature. Studying Kashgari's work scientist says: "Kypshak materials given in Kashgari's book displays first descriptions of modern Kazakh language". For the first time this was a very bold opinion. So each language place in Turkic language group starts from Kashgari's glossary. In addition turkologist A.N.Samoilov divided Turkic languages into 6 groups:

1. Bulgar or Chuvash group;

2. Uygyr or North-east group;

3. Mountain group, kypshak or north-west group;

4. Tagylyk group, shagatai, south-east group;

5. Tagly group, kypshak-turkmen or middle group;

6. Ol group, turkmen or south-west group (Amanzholov, 1997).

Quoting Akhmet Baitursynov, who left significant trace in any field of Kazakh linguistics, "Aim of the language to serve to express from mind's observations, fantasy's wanders and mood's conclusions" (Baitursynov, 1991). In order to find important objectives of the language we need to study achievements from people's spiritual experience and writing monuments from historical heritage. Thus writing monuments of Orhon-Yenisey shouldn't only be compared to Kazakh language, but also developed and it's another important task. A.Saadi concludes his opinion regarding to Kazakh language: "If there's the clearest, richest, the most natural language that saved in its initial state it is Kazakh language and Kazakh literature, and we should announce it to the science" (Saadi, 1926). So to show the beauty of this clear and rich language we seek for the history of language written materials that show the state of language in every historical period is the basis and lineage of language history. For example, archetypes of some of the auxiliary words in Kazakh language can be found some of the Orhon-Yenisey writing monuments. Now, especially when studying language's old heritage, we need to study it in its initial form, without altering anything. They weren't written for experiments of modern specialists (Zhubanov, 1978). And for the substantiation of object of research by theoretical conclusion, we need to consider them not as construction material but as one of the scientific principles. Only when lexical-grammatical description of auxiliary words in old Turkic writing monuments will be scaled together with theoretical basis of modern Kazakh language development, its principal importance and cumulative features will increase. Within this, the main principle of study is to consider lexical-grammatical features of auxiliary words in writing monuments. The aim is to find differences and similarities between auxiliary words in Kazakh language and the level of part of speech. This is not only the problem in Kazakh language history but also in separate Turkic languages. Auxiliary words as categories rely on ancient Turkic runic writing monuments. It's supported by written evidences of Orhon-Yenisey, Talas, and until this time we couldn't identify their root, suffix, affix. But time requires studying it and evaluating, because Orhon-Yenisey is a heritage common for Turkic languages and interest foreign scientists. They know that discoveries should be made not out of from nothing but from something existent. Further we pay attention to signs in monuments. We need to review works in Orhon-Yenisey writing monuments language's role in syntax from collocation point of view, because collocation is the first step in syntax levels. Syntactical relations first of all can be observed in collocation. And in order to create collocation 
,separate words must serve each other. Only this kind of coherence helps to create phraseological (collocation) unit. In ancient writing monuments of old Turkic language these units of auxiliary words have lexical-grammatical meanings. There we need to understand that syntactical relation is the connection between main words and auxiliary words, interactions of words in a sentence and the connection of separate sentences. In sentence combination of words is achieved through various grammatical methods. As a result, they create additional grammatical meaning, define the sentence's function and harmonize with it. It's known that auxiliary words don't only connect one words with others but also give it grammatical tones. M.I.Steblin-Kamensky it: "Grammatical meaning should be considered in connection with the function of the word in the act of speech. Each group plays has different functions in thinking: lexical meaning give material for the thinking process, and forms its grammatical meaning" (Steblin-Kamensky, 1974). These features can be observed in auxiliary words in ancient Turkic runic language. For example: I indifferently faced iron door - I encountered Iron Gate. From syntactical and morphological points, this sentence fits the norm of modern language. Within it, to show the overall syntactical level of auxiliary words we take it as example and analyze. So, firstly, "faced door" is an analytical formant that connects nominal word and verb. Which means it connects word and verb with the help of affix. Secondly, this collocation means that action spreads, finishes. Thirdly, it has a function in a sentence. Scientists have their conclusions on these monuments from historical grammar side.

In our language lots of words are used with additional meaning and have a function of grammatical tool. In the whole history of language development they've lost lexical meanings in various levels and gained some grammatical meanings. Even though lexical-grammatical meanings of auxiliary words are abstract when they are individual words, but among other word it become concrete. Commonly grammatical meaning of auxiliary words surpasses its lexical meanings. In monuments of Talass and Orhon-Yenisey functions of auxiliary words are shown in different levels. Some of them determine grammatical connections between words, and others are used to define words, add something to it or give various tones.

Also, as we observed in ancient writings, in development of morphological structure, there're shifts of morphological figures. Even if morphemes in word divided keeping its initial form, as time passes, it started to divide differently according to frequency of usage. In such cases, it's often the shift of sound to the root. Other times, it can be vice versa, and sound from root shift to the affix. Some affixes are kept in south-west languages, and in north-west languages they're replaced. In words "men, sen" in Kazakh language and "ben, sen" in Turkic language, the last sound shifted to affix and affix itself kept in that way (Kononov, 1956). This system is also repeated in nouns. In some languages, last elements of words shifted to previous affix (Kotvish, 1962).

In language structure that has been developing for centuries there're elements of dynamic development as well as factors of ancient times. In works of aforementioned scientists linguistic units of ancient Turkic languages have undergone changes. Scientists have said that historical development of language is defined not only by its comparison to related languages but also by study of its linguistic units. The modern verbs that we use now start off from ancient Turkic writings. M. Tomanov writes: "...in "Kutadgu bilik" the verb "qartaiu" (to get old) used in form "qary" (as definite verb). Thou in modern word "qartai" the letter " $t$ " is an affix that joined with old root. It's also clear when compared to adjective "qariya" (old man.) Also the words "qaldyk, tasqyn, kerek, baq, qaiyq, qysqash" in Kazakh language can be analyzed as initial root and "dead" affix" (Tomanov, 2010) therefore stating that the letter "q" together with the root of dead affix creates one word. Young specialist in his experience can teach morphological development if mother tongue through explanatory and research method.

Changes and innovations in educational system need constant improvement of specialist's professional competence. Our modern educational system need specialists, who keep our history, help to develop and update society and country and engage in self-improvement. This is why the formation of teacher's competence is paid special attention. And teachers with high professional skills and creative thinking are in demand.

\section{Concluding Remarks}

In this philological research we learned that well-known scientist M.Tomanov's study of ancient Turkic languages contributed to the formation of historical grammar, S.Maslov classified language life by their age, A.N.Samoilovich classified by tribal and geographical place. We also learned from theoretical aspect that each language's place in Turkic language bases on M.Kashgari's glossary and verbs, which we use now are come from the conjunction of root and dead affix in Orhon-Yenisey writing monuments. In connection with this, to improve future specialists' professional competence through teaching grammar, the following requirements should be given:

study of linguistic units in ancient Turkic languages in comparison with modern usage of words;

- $\quad$ to teach learners how to name indicators of morphological development; 
- professional knowledge and skills;

- ability to systematize historical grammar of Kazakh language;

- $\quad$ ability to make conclusions on classification of Turkic languages

So we found out that in the process of grammatical formation various variants of one unit can differentiate from grammatical meaning, and each of them may have grammatical and semantic meaning. These facts often met in Kazakh language too. The words like: "qystaq, gystau, baq, bau, taq, tau, adyr, aiyr" are in one grammatical row but sound different. Observing grammar from historical point of view, we see that if sounds are similar to each other, words that derivate from them are nouns and verbs.

\section{References}

Amanzholov S. (1997). Issues of dialectology and the history of the Kazakh language. Almaty.

Baitursynov A. (1991). Ak Jol. Almaty: Zhalyn,.p.493.

Klimov, E.A. (2003). Way to professionalism (Psychological analysis): Textbook. Moscow: Moscow Psycho-Social Institute; Flint, $320 \mathrm{p}$.

Kononov A.N. (1956). The grammar of the modern Turkish language. Moscow, p.127.

Kotvich V. (1962). Study on Altaic languages. Moscow, p.250.

Markova, A.K. (1996). Psychology of professionalism. - M.: International Humanitarian Fund "Znanie", p.312.

Saadi A. (1926). Til, adebiet, yazu am olardyn osuleri. Kazan: Tatgosizd, p.127.

Steblin-Kamensky M.I. (1974). Controversial in linguistics. St-Petersburg, p.69.

Tomanov, M. (1988). Historical Grammar of Kazakh language. Almaty: Mektep, 264 p.

Tomanov M. (2010) Anthology of Kazakh linguistics. Historical grammar of Kazakh language. Pavlodar State university after S.Toraygyrov, p.412.

Zhubanov A.K. (1978). Kumansha - kazakhsha zhilik sozdik Almaty: Kaz.SSR AS - Institution of Linguistics, p.277. 